\title{
Fluorescein angiography in a horse with optic nerve atrophy
}

\author{
Anika Pachten, Gabriele Niedermaier, Bettina Wollanke und Hartmut Gerhards \\ Equine Clinic of the Ludwig-Maximilians-University of Munich
}

\begin{abstract}
Summary
A 13 year old criollo gelding was referred because of a non-healing wound after enucleation of the right eye. During examination blindness of the left eye was additionally noticed. A thorough physical and ophthalmoscopic examination as well as photographic documentation and fluorescein angiography were performed. All photographs were taken with the Wild Medtech Scanning Digital Ophthalmoscope ${ }^{\circledR}$ (SDO), an indirect color ophthalmoscope. The SDO is equipped with a color video camera for recording color images, and a black and white camera for fluorescein angiography that is equipped with a special filter system. It can be easily positioned in the field of view to allow detection of abnormalities in the retinal vascularisation. Due to the fluorescein angiography the clinically suspected optic nerve atrophy could be confirmed and most likely the reason was a space occupying process based on the squamous cell carcinoma. Fluorescein angiography with the SDO were tolerated by the standing horse without any problems. A dosage of $2 \mathrm{mg} / \mathrm{kg}$ of $10 \%$ sodium fluorescein delivered satisfying results. Reported adverse reactions were not observed. Fluorescein angiography is a valuable ancillary diagnostic aid to the ophthalmologic examination and documentation when there is a guarded prognosis for retaining vision. Interesting findings in the vascularisation of the fundus can be more thoroughly discussed. Due to its compact size, ease of handling, and mobile application, the Scanning Digital Ophthalmoscope ${ }^{\circledR}$ is suitable for use in equine ophthalmology.
\end{abstract}

Keywords: ophthalmology, optic nerve atrophy, fundus, angiography, equine, fluorescein

\section{Fluoreszin-Angiographie bei einem Pferd mit Sehnervatrophie}

Ein 13jähriger Criollowallach wurde wegen einer nicht verheilenden Wunde nach einer Enukleation des rechten Auges in der Klinik für Pferde der Ludwig-Maximilians-Universität München vorgestellt. Im Verlauf der Untersuchung wurde zusätzlich eine Erblindung am linken Auge festgestellt. Eine sorgfältige Allgemeinuntersuchung sowie eine opthalmoskopische Untersuchung mit Fundusfotographie und einer Fluoreszenzangiographie wurden durchgeführt. Alle Fotographien wurden mit dem Wild Medtech Scanning Digital Ophthalmoskop ${ }^{\circledR}$ (SDO), einem indirekten Farbophthalmoskop, durchgeführt. Das SDO isł mit einer Farbkamera sowie einer Schwarz-Weißkamera und einem speziellen Filtersystem für die Fluoreszenzangiographie ausgestattet. Die Sehnervscheibe ist leicht im Bildfeld zu positonieren, so dass Abweichungen der retinalen Vaskularisation festgestellt werden können. Aufgrund der Fluoreszenzangiographie konnte die klinisch bereits vermutete Sehnervatrophie bestätigt werden. Mit allergrößter Wahrscheinlichkeit lag die Ursache in einem raumfordernden Prozess durch das Plattenepithelkarzinom. Die Fluoreszenzangiographie wurde vom stehenden, sedierten Pferd gut toleriert. Eine Dosierung von $2 \mathrm{mg} / \mathrm{kg}$ einer 10\% Natrium-Fluoreszeinlösung lieferte zufriedenstellende Ergebnisse. Von anderen Autoren berichtete Nebenwirkungen konnten nicht beobachtet werden. Die Fluoreszenzangiographie ist eine zusätzliche und nützliche Diagnosehilfe in der ophthalmologischen Untersuchung und Dokumentation, wenn eine vorsichtige Prognose für den Erhalt der Sehfähigkeit durch Störungen der retinlane Vaskularisation vorliegt. Interessante Befunde im Bereich der retinalen Gefäße können weitergehend diskutiert werden. Wegen seiner kompakten Größe und der einfachen und mobilen Anwendung isł das Scanning Digital Ophthalmoskop ${ }^{\circledR}$ für den Einsatz in der Pferdeophthalmologie gut geeignet.

Schlüsselwörter: Ophthalmologie, Sehnervatrophie, Fundus, Angiographie, Fluoreszein

\section{Introduction}

Fluorescein angiography, a diagnostic tool in veterinary medicine for many years is used to characterize normal and abnormal vascular conditions of the ocular fundus. However, the equipment available until recently was insufficient to perform routine fluorescein angiography in horses (Lescure et al. 1998). This case report documents the findings in a horse with a squamous cell carcinoma and related blindness, and the importance of fluorescein angiography as a diagnostic procedure in ophthalmic cases.

The gelding was referred because of a non-healing wound after enucleation of the right eye. In the cause of the exami- nation additionally blindness of the left eye has been noticed. The following a thorough physical and ophthalmoscopic examination as well as photographic documentation and fluorescein angiography were performed under pharmacological dilation of the pupil (Tropicamid, Mydriaticum Stulln ${ }^{\circledR}$, Fa. Pharma Stulln GmbH, Germany) and sedation (0,02 $\mathrm{mg} / \mathrm{kg}$ bwt Detomidine and 0,075 mg/kg bwt L-Methadone) with the horse in a stock. The horse's head was supported on the shoulder of the holder. All photographs were taken with the Wild Medtech Scanning Digital Ophthalmoscope ${ }^{\circledR}$ (SDO). The SDO functions as an indirect color ophthalmoscope with a $50^{\circ}$ angle of view. Due to its compact size and ease of handling, the camera is suitable for mobile application in equine ophthalmology. The linear scanning technique 
utilized by the SDO provides quality images, which are rich in contrast. This is especially useful when opacities in the anterior segment of the eye are present. Both single images and real-time video sequences can be obtained. Maximum video duration is 60 seconds, and a total of up to 50 single images can be recorded during a single sequence. The SDO is equipped with a color video camera for recording color images, and a black and white camera for fluorescein angiography. The ultra-sensitive black and white camera is equipped with a special filter system that can be easily positioned in the field of view to allow detection of abnormalities in the retinal vascularisation. The camera illuminates the retina by confocal scanning utilizing a halogen light source with the intensity of a slit lamp. Therefore, all images can be recorded in real time, which is advantageous when performing fluorescein angiography. The SDO is also equipped with an automatic timer, which allows for easy chronological archiving of images.

The dye used in this study was $10 \%$ sodium fluorescein (Fluorescein Alcon 10\%, Alcon, Germany). It was injected into the left external jugular vein at a dosage of $2 \mathrm{mg} / \mathrm{kg}$ bwt. Electroretinography (ERG) was performed using the RETlportÒ Laptop version from Acri.Tec (Henningsdorf, Germany)

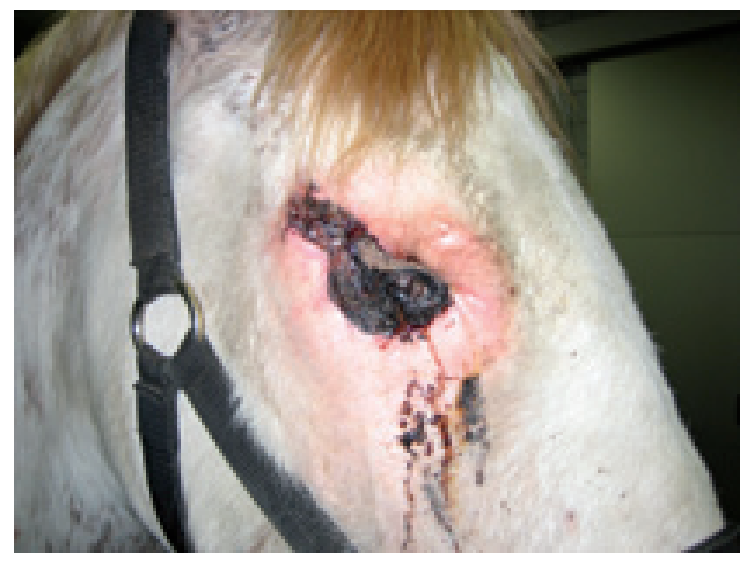

Fig. 1 Right orbit with granulation tissue and maggots

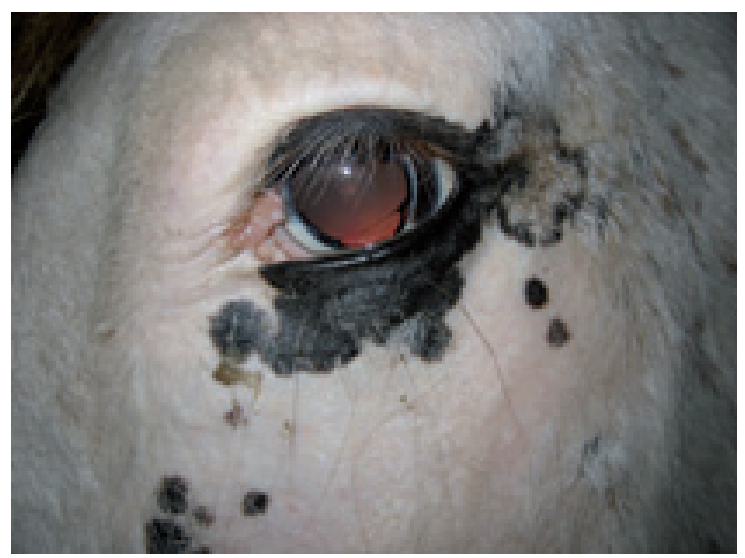

Fig. 2 Left eye

\section{History}

The 13-year-old Criollo gelding has been purchased five months prior to referral. At this point some kind of neoplasm has already been removed surgically at the right eye. Two weeks later the referring veterinarian enucleated the right eye because of an infiltrative growing tumor involving the entire cornea as well as part of the eyelids. No pathologic examination has been performed. It was necessary to remove large parts of the eyelids so the wound had to heal by secondary intention. The gelding went home three weeks after surgery. Since two weeks the owner has observed bloody discharge from the right nostril. Additionally there were recognised a bunch of maggots in the wound so it was that the gelding was presented to the Equine Clinic of the LMU. The owner did not previously notice signs of inflammation or impaired vision at the left eye.

\section{Clinical Findings}

The gelding presented as a chronically ill horse. Additionally the right mandibular lymph node was enlarged and in the right nostril bloody discharge could be observed. An endoscopic examination revealed a narrowed nasal passage and the discharge did not origin from the nasolacrimal duct as it was supposed to do. But the actual origin could not be detected. On lateral x-rays of the head there was a well defined nodular soft tissue opacity in the area of the right globe. In the orbi-

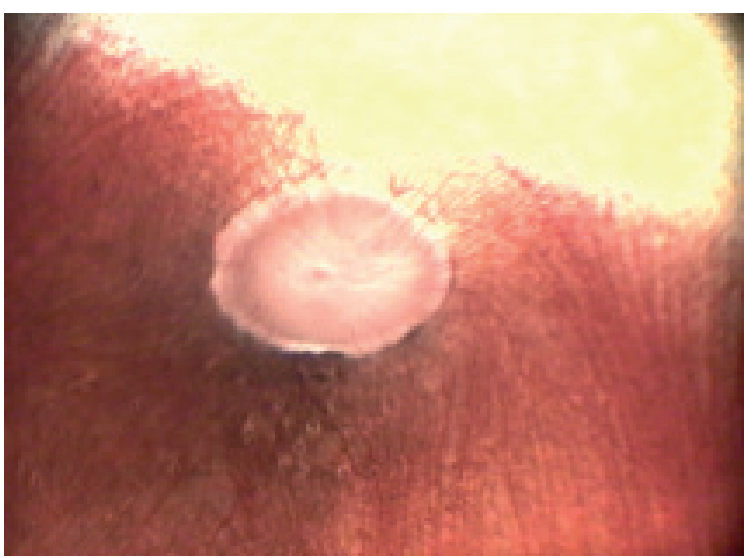

Fig. 3 Left ocular fundus: pale optic nerve head and diminished retinal vessels

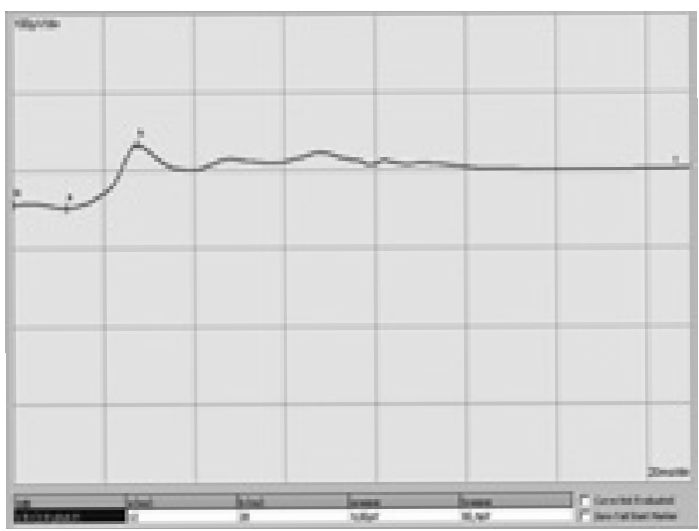

Fig. 4 ERG: a slightly reduced response in the left eye

tal region there was a $10 \times 10 \mathrm{~cm}$ area of necrotic granulation tissue and the orbit itself was filled with maggots (Fig. 1). After careful debridement and flushing of the wound a sample of the granulation tissue has been taken for pathohistologic examination. It came out to be a squamous cell carcinoma. In 
the nasal region of the unpigmented left upper eyelid grew a $10 \times 5 \mathrm{~mm}$ pink mass. During a complete ophthalmoscopic examination of the left eye mydriasis, a heterochromic iris, a persistent pupillary membrane, an atypical iris coloboma at 5 o'clock and a focal cataract were detected (Fig. 2). There was a partial albinism of the fundus. The optic nerve head seemed pale and retinal vessels could hardly be identified (Fig. 3). The pupillary light reflex was negative and the menace response was reduced. An ERG was performed, and revealed an almost normal electric response of the retina (Fig. 4). A total of 1000 $\mathrm{mg}$ of Fluorescein were injected into the left jugular vein. The distribution of the dye in the left eye was documented using real-time video sequences and an automatic timer. Latency time was 41 seconds. The retinal vessels could only be weakly visualized (hypofluorescence), and appeared to be diminished in number. Additionally, fluorescence of the large choroidal vessels could be seen through the albinotic fundus. This hyperfluorescence made it almost impossible to determine the beginning of the recirculation time, which was estimated to have begun approximately after 77 seconds (Abb. 5).
1937, Modes et al. 1936). In the dog, the fluorescein angiogram consists of 5 (or 6) phases: 1. latency time, 2. choroidal phase, 3. retinal arterial phase, 4. retinal capillary (arterio-venous) phase, 5. retinal venous phase, 6. recirculation time with fluorescein recirculation waves from the periphery (Lescure et al. 1998, Strubbe et al. 1998, Gelatt et al. 1981, Gelatt et al. 1991, Walde et al. 1970, Walde et al. 1977). In the paurangiotic fundus of the horse it is not possible to classify individual phases of the fluorescein angiogram like in a holangiotic fundus. This makes the interpretation a challenge (Lescure et al. 1998). There is a sudden appearance of many small vessels; distribution is fast and differentiation between arterial and venous phases is not possible. Due to the short and small diameter of the vessels, laminar flow, as seen in the dog, is lacking in the horse. The recirculation time is long in duration and demonstrates a constant fluorescence. Ultimately, it is possible to differentiate between: latency time $(22$ seconds), retinal distribution time (20.5 seconds), and recirculation time (2 to 5 minutes) with 1 or 2 recirculation waves, in adult warmblood horses (Walde et al. 1970, Walde et al.

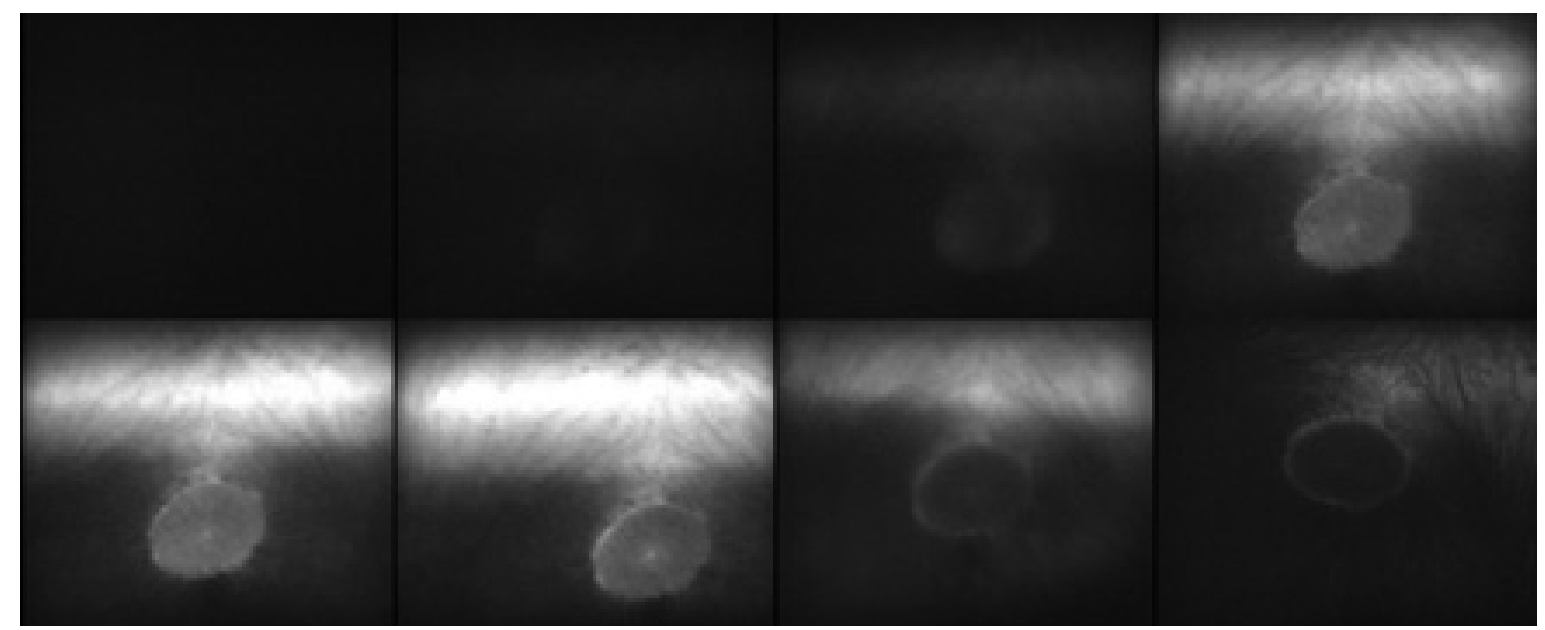

Fig. 5 Fluorescein angiography of the left eye. From left to right and from top to bottom: $22 \mathrm{sec}, 41 \mathrm{sec}, 45 \mathrm{sec}, 54 \mathrm{sec}, 58 \mathrm{sec}, 64 \mathrm{sec}, 77$ $\mathrm{sec}, 80 \mathrm{sec}$

Even though a magnet resonance tomography was highly indicated for further diagnostics the owner did not agree to this expensive examination under general anaesthesia.

\section{Diagnosis}

Apart from the malignant and infiltrative growing squamous cell carcinoma in the right orbit and probably at the left upper lid an atrophy of the left optic nerve and almost complete central blindness was diagnosed. Although the prognosis was poor the owner did not want to euthanize the gelding at this point and a postmortem neuropathologic examination could not be carried out.

\section{Discussion}

Modes demonstrated in the late 1930's using injectable compounds, that the horse, in comparison to other domestic animals, has no central retinal artery; but rather, the peripapillary retinal vessels emerge from the Zinn vessels. The horse has a paurangiotic fundus and the determination of veins and arteries is not possible ophthalmoscopically (Modes et al.
1977). The following parameters must be considered when evaluating a fluorescein angiogram: 1. duration of the individual phases, 2. dye intensity (hypofluorescence, hyperfluorescence), and 3. reference to color photographs of the normal fundus to reduce the chance of misinterpretation (Lescure et al. 1998, Strubbe et al. 1998).

Fundus photography and fluorescein angiography with the Scanning Digital Ophthalmoscope ${ }^{\circledR}$ of the Wild Medtech Company was tolerated by the standing horse without any problems. Akinesis of the animal during the procedure was of utmost importance. Therefore, a dark and quiet examination room was useful in reducing anxiety. After a few minutes, the noise from the camera's ventilation system was no longer a problem. Walde performed the fluorescein angiography at the horse in 1970 without sedation. He considered the lowered upper eyelid, the prolapsed nictitating membrane, and the lowered head as result of sedation undesirable. He acknowledged that general anaesthesia allows uninterrupted and thorough visualisation, but there is an increased demand on personal and it is much more time consuming (Walde et al. 1970). Because even a single movement can interrupt the sequence recording in an angiography, Strubbe and Gelatt recommend 
that small animals be sedated and that horses be put under general anesthesia, despite these disadvantages (Strubbe et al. 1998, Gelatt et al. 1981, Gelatt et al. 1991). In our opinion, light sedation and placing the horse into a stock are recommended in order to protect the personal, the horse, and the equipment from injury or damage, respectively.

Fluorescein angiography in the standing horse can be performed easily with adequate restraint, sedation and calm handling. All authors agree that the pupil should be dilated prior to examination (Lescure et al. 1998, Strubbe et al. 1998, Gelatt et al. 1981, Gelatt et al. 1991, Walde et al. 1970, Walde et al. 1977). Walde recommends in his thesis $8-10 \mathrm{mg} / \mathrm{kg}$ of $20 \%$ sodium fluorescein as the optimal dosage for the horse (Walde et al. 1970, Walde et al. 1977). In the described case, as well as in other horses (Pachten et a. 2008) a dosage of $2 \mathrm{mg} / \mathrm{kg}$ of $10 \%$ sodium fluorescein delivered satisfying results. On the contrary, too large of a dosage actually leads to a decrease in fluorescence intensity, due to self obliteration, (Walde et al. 1970). Reported adverse reactions, such as agitation following injection, nausea and emesis, allergic or anaphylactic reactions, and thrombophlebitis following paravenous injection (Strubbe at al. 1998, Walde et al. 1970) were not observed.

In this particular case the transmitted fluorescence of the large choroidal vessels due to the fundus albinism made it hard to differentiate the ocular fundus structures. In the literature this is referred to as the 'choroidal window defect' in the tapetal zone and 'retinal window defect' in the non-tapetal area and leads to hyperfluorescence (Lescure et al. 1998).

But all together there was a clear hypofluorescence of the optic disc and retinal vessels. Hypofluorescence means most often a lack of fluorescence, in an area that should normally be fluorescent at a given time. It can result from two phenomena: a masking or a filling defect (Lescure et al. 1998). As a global delayed filling is estimated by the data given by the timer as compared with the average reference times the extended latency time of 41 seconds, compared to data from the literature (22 seconds), can be explained (Walde et al. 1970, Walde et al. 1977). Additionally the retinal distribution time of 36 seconds was much longer than previously reported (20.5 seconds) (Walde et al. 1970, Walde et al. 1977); indicating diminished retinal perfusion maybe caused by a loss or occlusion of retinal vessels (Lescure et al. 1998, Strubbe et al. 1998, Gelatt et al. 1998, Gelatt et al. 1998). Ischaemic injury to the nerv is finally followed by optic nerve atrophy and this atrophy is generally accompanied by atrophy of the retina (Barnett et al. 2004, Cutler et al 2000). Multiple causes have been suggested for optic nerve atrophy including inflammatory diseases and noninflammatory conditions like trauma, blood loss, glaucoma, intoxication, external compression and neoplasia (Barnett et al. 2004, Cutler et al 2000, Gilger et al. 2005). Performing of a magnet resonance tomography would have been gained further information about the extension of the squamous cell carcinoma and the origin of the bloody nasal discharge. But due to the fluorescein angiography the clinically suspected optic nerve atrophy could be confirmed and with the utmost probability the reason was a space occupying process based on the squamous cell carcinoma. These carcinomas arise from any epithelial surface or epithelial transition, but they are locally aggressive and if the tumor is extensive enough invasion of the periocu- lar and orbital tissue is possible (Barnett et al. 2004, Gilger et al. 2005). Therefore the expensive MRI under general anaesthesia was avoided. Nevertheless the grave prognosis and the indication for euthanasation could be backed up: If there is any indication of tumor extension into the orbit or even into the orbit bones treatment is unlikely to be successful (Barnett et al. 2004). Additionally there is no treatment for optic nerve atrophy and the prognosis for vision is poor (Barnett et al. 2004, Gilger et al. 2005)

\section{Conclusions}

Analogue to human medicine Fluorescein angiography is a valuable ancillary diagnostic aid to the ophthalmologic examination and documentation when there is a guarded prognosis for retaining vision. Interesting findings in the vascularisation of the fundus can be more thoroughly discussed. Due to its compact size, ease of handling, and mobile application, the Scanning Digital Ophthalmoscope ${ }^{\circledR}$ is suitable for use in equine ophthalmology. In the future there will certainly be further advancements improving image quality. Presently, fluorescein angiography is still reserved for use in referral clinics, due to the expense of the equipment, and its limited application.

\section{References}

Barnett K. C., Crispin S. M., Lavach J. D. and Matthews A. G. (2004) Equine Ophthalmology: An Atlas and Text. Elsevier (USA)

Cutler T. J., Brooks D. E., Andrew S. E., Denis H. M., Biros D. J., Gelatt K. N., Komaromy A. M. and Kallberg M. (2000) Diseases of the equine posterior segment. Vet. Ophthal. 3, 73-82

Gelatt K. N.(1981) Ophthalmic examination and diagnostic procedures. In: Textbook of Veterinary Ophthalmology, 1st edition (ed. Gelatt KN). Lea \& Febiger: Philadelphia, 206- 264

Gelatt K. N. (1991) Ophthalmic Examination and diagnostic procedures. In: Textbook of Veterinary Ophthalmology, 2nd edition (ed. Gelatt KN). Lea \& Febiger: Philadelphia, 195- 236

Gilger B. C. (2005) Equine Ophthalmology. Elsevier (USA)

Lescure F. (1998) Fluorescein Angiographic Atlas of the Small Animal Ocular Fundus. Pratique Médicale et Chirurgicale de I' Animal de Compagnie CNVSPA, Paris

Modes E. (1936) Das Blutgefäßbild des Augenhintergrundes bei den Haussäugetieren. Archiv für wissenschaftliche und praktische Tierheilkunde. 79, 449-473

Modes E. (1937) Das Blutgefäßbild des Augenhintergrundes bei den Haussäugetieren. Inaugural- Dissertation, Universität Leipzig

Pachten A., Wollanke B., Gerhards H. und Stiersdorfer B. (2008) Fluorescein angiography in the diseased ocular fundus of two horses, Equine Vet. Educ. 20, 11-15

Strubbe D. T. and Gelatt K. N. (1998) Ophthalmic examination \& diagnostic procedures. In: Textbook of Veterinary Ophthalmology, 3rd edition (ed.Gelatt KN). Williams and Wilkins, Baltimore, 427- 466

Walde I. (1970) Fluoreszenzangiographie der Netzhautgefäße bei Pferd und Hund. Vet. Med. Diss. Wien

Walde I. (1977) Das Fluoreszenzangiogramm des normalen Augenhintergrundes bei Hund und Pferd. Tierärztliche Praxis. 5, 343347

Dr. Anika Pachten

Universität München

Klinik für Pferde

Veterinärstraße 13

80539 München

anika.pachten@freenet.de 